\title{
ASSOCIATION BETWEEN FEEDING PATTERN AND NUTRITIONAL STATUS AMONG TODDLERS, IN JOMBANG, EAST JAVA
}

\author{
Tri Ratnaningsih, Chatarina Umbul W \\ Faculty of Public Health, Airlangga University, Surabaya
}

\begin{abstract}
BACKGROUND: To develop the optimal potential of children, it is vital that they are provided with nutritionally sound diets. Diet and exercise patterns during childhood and adolescence may spell the difference between health and risk of disease in later years. Different stages of the life cycle dictate differing nutrient needs. This study aimed to describe feeding pattern and to determine the association between feeding pattern and nutritional status among children aged 1 to 5 years old, in Jombang, East Java.
\end{abstract}

SUBJECTS AND METHOD: This was a cross sectional study, conducted in Jombang, East Java. A sample of 72 children aged 1 to 5 years old (toddlers) were selected from Carangwulung village, Wonosalam district, Jombang regency, East Java. The dependent variable was nutriational status, which was measured by weight for age according to WHO 2005. The independent variable was feeding pattern, including energy intake and protein intake. Feeding pattern was measured by 24-hour food recall questionnaire. Nutrient adequacy in meeting the energy and protein requirement per day was measured by Nutrisurvey software. The association between energy and protein intake and nutritional status was analyzed by Odds Ratio (OR) and Chi-Square test.

RESULTS: There was a strong and positive association between energy intake and nutritional status in children aged 1 to 5 years old. Children with good energy intake were 19.72 times more likely to have good nutriational status those with poor energy intake $(\mathrm{OR}=19.72 ; 95 \% \mathrm{CI}=2.45$ to 158.90; $\mathrm{p}<0.001)$. There was a strong and positive association between protein intake and nutritional status in children aged 1 to 5 years old. Children with good protein intake were 19.09 times more likely to have good nutritional status those with poor protein intake $(\mathrm{OR}=19.09$; $95 \%$ $\mathrm{CI}=4.96$ to $73.52 ; \mathrm{p}<0.001$ ).

CONCLUSION: Both energy and protein intake are strong predictors for nutritional status among children aged 1 to 5 years old. Children with good energy and/or protein intake are more likely to have good nutritional status.

Keywords: feeding pattern, energy intake, protein intake, nutritional status, toddler 